10.23860/JMLE-2019-11-2-3

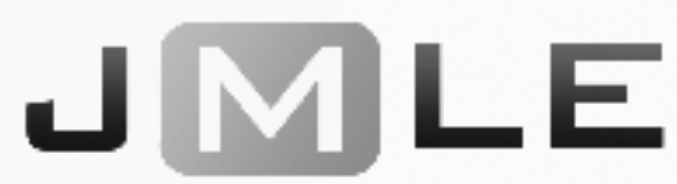

The National Association for Media Literacy Education's Journal of Media Literacy Education 11 (2), 37 - 55

\title{
Assessing Online Viewing Practices among College Students
}

\author{
Elizabeth J. Threadgill \\ Utica College, USA \\ Larry R. Price \\ Texas State University, USA
}

\begin{abstract}
This article focuses on media literacy education for college students. First, we conducted psychometric analyses to verify the properties of the Critical Evaluation and Analysis of Media (CEAM) scale. CEAM measures college students' self-reported practices for critically evaluating and analyzing the credibility, audience, and technical design elements of online media, such as news, advertisement, and entertainment media. Using CEAM, our second goal was to identify trends in critical viewing practices among first-year students enrolled in college. Results of confirmatory factor analysis (CFA) and item response theory (IRT) supported a three-factor structure for the CEAM scale. Composite score reliability for all items comprising the total scale displayed strong evidence for the internal consistency of the scale with a Coefficient Alpha $(\alpha)$ of .91. Score reliability estimates for each subscale follow: (a) Questioning Credibility $(\alpha=.80$ ), (b) Recognizing Audience $(\alpha=.78)$, and (c) Recognizing Design $(\alpha=.81)$. Findings from the study indicate that while firstyear college students generally perceive they have adequate practices in recognizing audience in media messages and questioning the credibility of news, there is room for improvement in questioning the credibility of advertisements, suggesting that college instructors should focus more on advertising literacy.
\end{abstract}

Keywords: media literacy, advertising literacy, college, psychometrics

The Pew Research Center $(2011,2015,2017)$ found that college students and college graduates make up the highest percentage of adult internet users in the U.S. The media that these college students access on a daily basis is more portable than ever - think mobile devices and tablets - and, therefore, more pervasive, persistent, and participatory than ever before (Pew Research Center, 2014). In a review of existing studies on media literacy effects, Potter and Byrne (2009) found that "mass media are continually exerting all kinds of direct and indirect influences on individuals and society" (p. 346), and that these influences are often negative and can impact media consumers at the cognitive, affective, and behavioral levels. However, Potter and Byrne (2009) also found that when available, media literacy education tends to improve (a) critical thinking, (b) information processing, (c) 
awareness of persuasive techniques, and (d) social cognition (Potter \& Byrne, 2009).

And, yet, systematic media literacy education at the college level is largely nonexistent in the U.S. (Christ, 2004; Martens, 2010; Schmidt, 2013; Schwarz, 2014). Researchers identify some reasons we have not adopted systematic media literacy education: (a) there is little research, and, therefore, little consensus among researchers or instructors about what media literacy competencies to include in college curriculum or how to measure them (Christ, 2004; Kellner \& Share, 2005; Livingstone \& Wang, 2014; Schmidt, 2013), (b) static core curriculum and narrowly-focused standardized tests are a constraint to introducing new media literacy curriculum (Silverblatt, 2014), and (c) providing comprehensive media literacy education requires major actions at a policy level, and to enact such policies requires large-scale research and validation (Jolls \& Walkosz, 2014; Livingstone \& Wang, 2014).

Meanwhile, it is clear college students need improved media literacy skills. Brumberger (2011) found that college students self-assess their media literacy skills as being limited, and while students may suspect that images they see on the internet have been altered, they do not consistently critically question these images. Similarly, Ashley, Lyden, and Fasbinder (2012) found that when viewing news and advertisement videos online, college students focused on superficial elements, did not raise questions, and believed that media messages are straightforward. Researchers agree that college students benefit from media literacy education, especially in evaluation and analysis (Ashley, Lyden, \& Fasbinder, 2012; Brumberger, 2011; Duran, Yousman, Walsh, \& Longshore, 2008; Pernisco, 2014; Potter \& Byrne, 2009; Schmidt, 2013).

Evaluation and analysis are two of four core elements of media literacy outlined by the National Association for Media Literacy Education (NAMLE). NAMLE's core elements are the most commonly accepted in research about media literacy education at the college level (Ashley, Lyden, \& Fasbinder, 2012; Duran, et al., 2008; Mihailidis, 2011; Schmidt, 2012). Likewise, the College Board also recognizes the value of preparing students to interpret, analyze, and evaluate a variety of texts they will encounter in all subject areas. An excerpt from the College Board's Standards for College Success follows:

To be successful in college and in the workplace and to participate effectively in a global society, students are expected to understand the nature of media; to interpret, analyze, and evaluate the media messages they encounter daily; and to create media that express a point of view and influence others. These skills are relevant to all subject areas, where students may be asked to evaluate media coverage of research, trends, and issues. (Silverblatt, 2014, p. 424)

The College Board identified English Language Arts as one subject area that is especially equipped to teach interpretation, analysis, and evaluation of media messages. Similarly, Bordac (2009) interviewed faculty members teaching humanities and social sciences who stress the importance of different types of 
analysis, including critical and contextual/situational analysis, as well as synthesis. Schmidt (2013) found that college educators identify analysis as the most important media literacy competency for college students in any discipline. Pernisco (2014) points to a combination of analysis and evaluation as the most important, arguing that this combination allows students to think about the context and possible biases that might exist in the media message. As such, these two competenciesevaluation and analysis - form the foundation for the instrument we designed for this study. The first part of this study involved evaluating this instrument. Next, our primary goal was to learn about the critical viewing practices among first-year students enrolled in the college composition sequence in order to improve media literacy curriculum for first-year college students.

\section{METHODOLOGY}

First, we conducted psychometric analyses to verify the properties of the Critical Evaluation and Analysis of Media (CEAM) scale. CEAM measures college students' self-reported practices for critically evaluating and analyzing credibility, audience, and technical design elements of online media, such as news, advertisement, and entertainment media. As discussed previously, scholars have identified evaluation and analysis as the most important media literacy competencies within humanities courses and other disciplines (Bordac, 2009; Pernisco, 2014; Schmidt, 2013; Silverblatt, 2014). CEAM is a 27-item, 5-point Likert-type scale with responses ranging from "strongly disagree" to "strongly agree." This response scale is consistent with the intent (Gable \& Wolf, 1993) to measure students' perceptions about how they engage with media most of the time. Additionally, five gradations allow for balanced optimization of the instrument's reliability with careful, non-aggravated consideration from the respondents (Gable \& Wolf, 1993).

A variety of instruments have been used to measure media literacy (e.g., Arke \& Primack, 2009; Ashley, Lyden, \& Fasbinder, 2012; Chang, Liu, Lee, Chen, Hu, \& Lin 2011; Duran et al., 2008; Engeln-Maddox \& Miller, 2008; Eristi \& Erdem, 2017; Hobbs \& Frost, 2003; Literat, 2014; Primack, Gold, Switzer, Hobbs, Land, \& Fine, 2006; Quin \& McMahon, 1993; Vraga, Tully, Kotcher, Smithson, \& Broeckelman-Post, 2016). However, only a handful of these instruments focus on college students (e.g., Arke \& Primack, 2009; Duran et al., 2008; Engeln-Maddox \& Miller, 2008; Literat, 2014; Vraga et al., 2016). Some of the instruments that do target college students are too narrowly focused. For instance, the Knowledge of Media Structures and Media Influence scales developed by Duran et al. (2008) are specific to curriculum developed at one institution. Similarly, the Critical Processing of Beauty Images (CPBI) scale created by Engeln-Maddox and Miller (2008) is only focused on analysis and evaluation of media messages featuring idealized women.

Other instruments are outdated. For example, the instrument developed by Arke and Primack (2009) is outdated in that it only measures old media (media available through the traditional routes of television, radio, and print) as opposed 
to new media (media available on the internet). Literat (2014) developed a more comprehensive and modern instrument; however, the items in this scale focus more on digital literacy and information literacy than media literacy. CEAM is geared toward college students, and items are comprehensive, addressing news, advertisement, and entertainment media available online.

Using CEAM, our goal was to identify trends in critical viewing practices among students enrolled in developmental writing and first-year composition courses at the college level. As discussed previously, scholars have suggested that evaluation and analysis are skills that fit naturally in humanities courses (Bordac, 2009; Silverblatt, 2014). In Fall 2015, a purposive sample was taken from students enrolled in the first-year composition sequence at a large public institution in central Texas that is designated as an Hispanic-Serving Institution (HSI). Sixteen instructors teaching 26 sections agreed to allow the research team to administer the scale. The scale was administered at the beginning of the semester so as to ensure the responses were not a result of instruction in media literacy. In all instances, the instructor of the class left after the instructions were given and remained outside the room until all scales were turned in (completed or blank).

A total of 322 first-semester students completed all items on the scale. For the 27-item scale, the total of 322 participants is satisfactory as per the rule of thumb for factor analysis specifying 10 subjects per item (Nunnally, 1978); additionally, this is a good sample size based on Comrey and Lee's (1992) scale of sample size. Of those students in the Fall 2015 sample with complete demographic information available, $59 \%$ of students were female, and $40 \%$ were male. See Figure 1 for the ethnicity/race breakdown.

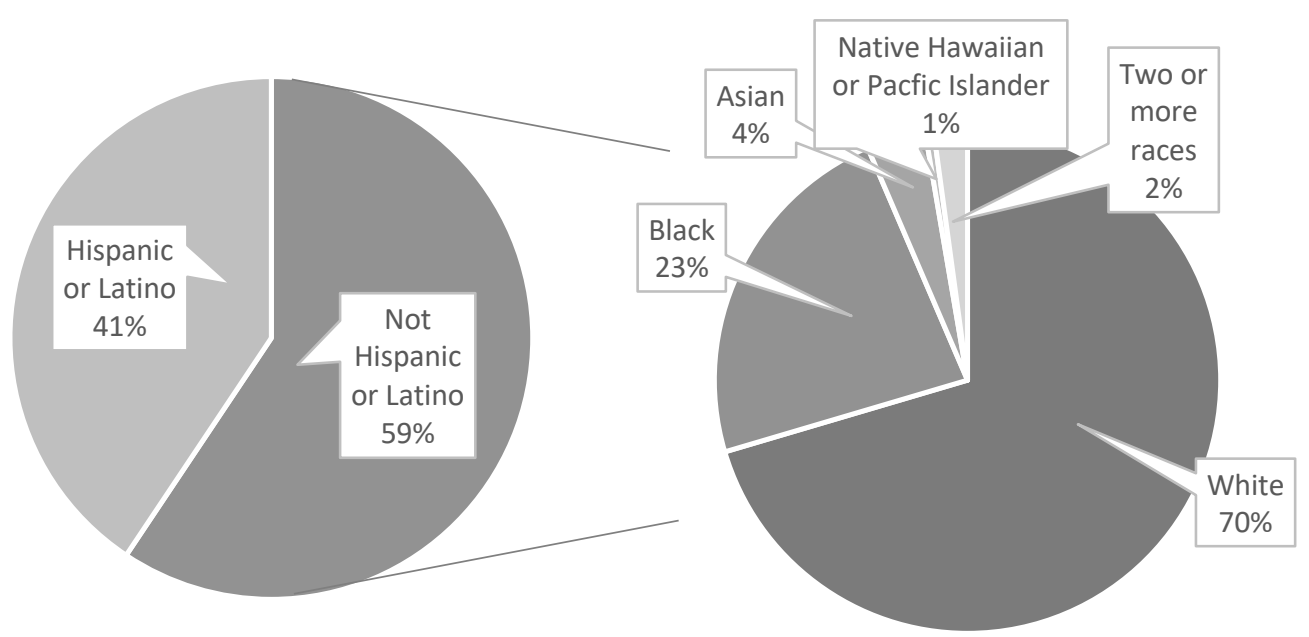

Figure 1. Ethnicity/race for Fall 2015 sample. This figure illustrates the complex race/ethnicity category for students within the sample.

Using this data set, we conducted a confirmatory factor analysis (CFA) in order to determine model fit, validity, and reliability of CEAM. We then used item response theory (IRT) to determine the generalizability of CEAM. As a sample- 
free measurement, IRT allows for such a determination (Hambleton, Swaminathan, \& Rogers, 1991; Price, 2016). IRT also allows researchers to examine both the ability (a.k.a. latent trait) of persons and the characteristics of items in an instrument (de Ayala, 2009; Price, 2016).

\section{RESULTS}

Findings indicate that CEAM is a valid and reliable self-report instrument for measuring media literacy among college students. Findings also indicate that while first-year college students generally perceive they have adequate practices in recognizing audience in media messages and questioning the credibility of news, there is room for improvement in questioning the credibility of advertisements.

\section{CFA}

In SPSS (IBM Statistics 23), principal axis factoring using an oblique (Promax) rotation was applied to the 27 items measuring students' self-reported critical viewing practices.

Before analysis, data screening was conducted. There were no missing values. Normality was also examined, with particular attention to skewness and kurtosis because of predicted issues with social desirability and acquiescence in the age of the "digital native" (Prensky, 2001). Responses were not normally distributed. However, Tabachnick and Fidell (2013) argue that skewness and kurtosis may not make a substantive difference in analysis of samples larger than 200. Factorability and sampling adequacy were favorable. With a Kaiser-MayerOlkin $(K M O)$ value of 9.1, the data were highly factorable. Bartlett's test of sphericity $\left(\chi^{2}=3053.231, \mathrm{df}=351, \mathrm{p}=.000\right)$ demonstrates that there are correlations in the data set appropriate for factor analysis.

Based on a review of the bivariate correlation analysis and an analysis of the content of the items, three factors were extracted using principal axis factoring with an oblique rotation. The first factor accounts for $31.401 \%$ of the total variance in the data set; the second factor accounts for $5.926 \%$ of the total variance in the data set; and the third factor accounts for $5.130 \%$ of the total variance in the data set. The loading weights for most items were strong. Loading weights should be above .32 (Tabachnick \& Fidell, 2013).

Analysis of item-to-total correlations also helped to determine the validity of the instrument. Item-to-total correlations were all above .3; a correlation of at least .3 is preferable (Cohen, Swerdlik, \& Sturman, 2012). Additionally, correlations among factors did not exceed .90 , so it can be assumed that while the items are all measuring the same construct, they are providing distinct information about the construct (Brown, 2006).

In an effort to build a comprehensive view of validity (Messick, 1987), qualitative methods of ascertaining validity were also used. Qualitative item analysis was used to improve face validity - that items, on the surface, appear to measure what they are intended to measure - and content validity - the appropriateness of the items and test format. Additionally, items were reviewed for clarity by a research community consisting of literacy specialists and assessment 
specialists; during the initial stage members of the research community participated in think-alouds (Cohen, Swerdlik, \& Sturman, 2012) to help narrow the item pool and revise the wording for stronger content validity. The feedback these researchers provided was used to simplify wording in the items in order to alleviate possible effects of item difficulty and item discrimination.

Results of the CFA supported a three-factor structure for CEAM. The three subscales of CEAM follow: (a) questioning credibility, (b) recognizing audience, and (c) recognizing design. Table 1 provides a complete list of the items for each subscale. Items address news, advertisement, and entertainment media.

Table 1.

Subscales of the Critical Evaluation and Analysis of Media (CEAM) Scale

Questioning Credibility Recognizing Recognizing Design

Audience(s)

12 I question a news story when credible sources for the ideas are not included.

03 I consider what viewpoints might be missing when I watch or read the news.

22 When watching or reading the news, I think about whether or not any images that are included accurately illustrate the content of the story.

08 I distinguish between expert sources and non-expert sources in news stories.

07 I think about how news stories can be designed to sway me with facts and logic.

24 When viewing an advertisement, I distinguish between facts and opinions about the product.

20 I think about the strategies news reporters use in news stories.

11 When watching or reading the news, I think about different purposes the story might have.

10 I think about how advertisements can be designed to sway me with facts and logic.
16 When watching a television show, movie, or video, I think about whether or not it would appeal to diverse populations.

19 When viewing an advertisement, I think about whether or not it would appeal to diverse populations.

26 I think about why some advertisements may appeal to different audiences.

06 When watching or reading a news story, I think about whether or not it would appeal to diverse populations.

27 I recognize that different news stories are written to appeal to people who have different values.

04 I think about why some television shows, movies, or videos may appeal to different audiences.
18 I think about how news stories can be designed to elicit an emotional response.

01 When I watch a commercial, I pay attention to how the music makes me feel.

02 I think about how television shows, movies, or videos can be designed to elicit an emotional response.

05 When watching television, movies, or videos, I think about the effect the editing techniques have on me.

13 When viewing an advertisement, I think about the effect the design has on me.

17 I think about how the design of advertisements can draw my attention to specific images.

09 If I see that a for-profit company is promoting a social cause in an advertisement, I recognize that the company is still advertising itself.

25 I think about the strategies advertisers use to promote their products.

21 I think about how advertisements can be designed to elicit an emotional response. 
14 When watching television, movies, or videos, I think about the lifestyles that are being promoted.

Composite score reliability for all items comprising the total scale displayed strong evidence for the internal consistency of the scale with a Coefficient Alpha ( $\alpha$ ) of .91 (Nunnally, 1978; Price, 2016). Score reliability estimates for each subscale were: (a) Questioning Credibility $(\alpha=.80)$, (b) Recognizing Audience ( $\alpha$ $=.78)$, and (c) Recognizing Design $(\alpha=.81)$.

\section{IRT}

A unidimensional IRT model was fit to item-level data based on the structure identified in the CFA. One assumption underlying IRT is unidimensionality-that the underlying set of items measures a single construct (Brown, 2006). In order to verify unidimensionality - that the subscales or factors are all measuring one construct or dimension - the model was first tested using a second-order confirmatory factor analysis in Mplus (version 7.4).

The results of the unidimensional second-order factor analysis revealed adequate model-data fit, $\chi 2(351)=3159.53, \mathrm{p} \leq .001$, RMSEA $=.07$ (.06-.07), CFI $=.90$. The chi-square global test of model fit was rejected indicating a lack of adequate model-data fit. However, the chi-square is highly sensitive to sample size (e.g., sample sizes $>100$ nearly always yield statistically significant findings).

To address this challenge, additional measures of fit were used to evaluate the fit of the model to the sample data. Specifically, the RMSEA point estimate was .08 with an upper confidence interval less than .08 , which is considered acceptable (Schumacker \& Lomax, 2004). Additionally, while the comparative fit index (CFI) was originally too low at .82, correlated error terms for the items were added to improve CFI. A CFI level of .90 or higher is viewed as being acceptable (Schumacker \& Lomax, 2004). Based on the factor analytic results, application of IRT to the item-level response data was deemed appropriate.

IRT was run using Item Response Theory for Patient Reported Outcomes (IRTPRO, version 3.1). Specifically, a MULTILOG graded response model (GRM) was used. Embretson and Reise (2000) recommend this model for data from Likerttype instruments in which the number of response options is consistent throughout. Results of the analysis revealed an IRT-based score reliability for the 27-item scale is high $(\alpha=.93)$. Internal consistency score reliability should be .80 or above (Nunnally, 1978; Price, 2016). Additionally, all standardized factor loadings were observed as .42 or above; factor loadings are satisfactory if above .32 (Price, 2016; Tabachnick \& Fidell, 2013). See Table 2 for the standardized factor loading weights for each item. 
Table 2.

Standardized Factor Loadings

\begin{tabular}{|c|c|}
\hline Media Literacy Items & $\begin{array}{l}\text { Standardized } \\
\text { Factor } \\
\text { Weights }\end{array}$ \\
\hline $\begin{array}{l}01 \text { When I watch a commercial, I pay attention to how the music makes me } \\
\text { feel. }\end{array}$ & .42 \\
\hline $\begin{array}{l}02 \text { I think about how television shows, movies, or videos can be designed to } \\
\text { elicit an emotional response. }\end{array}$ & .63 \\
\hline 03 I consider what viewpoints might be missing when I watch or read the news. & .59 \\
\hline $\begin{array}{l}04 \text { I think about why some television shows, movies, or videos may appeal to } \\
\text { different audiences. }\end{array}$ & .68 \\
\hline $\begin{array}{l}05 \text { When watching television, movies, or videos, I think about the effect the } \\
\text { editing techniques have on me. }\end{array}$ & .46 \\
\hline $\begin{array}{l}06 \text { When watching or reading a news story, I think about whether or not it } \\
\text { would appeal to diverse populations. }\end{array}$ & .57 \\
\hline $\begin{array}{l}07 \text { I think about how news stories can be designed to sway me with facts and } \\
\text { logic. }\end{array}$ & .60 \\
\hline 08 I distinguish between expert sources and non-expert sources in news stories. & .54 \\
\hline $\begin{array}{l}09 \text { If I see that a for-profit company is promoting a social cause in an } \\
\text { advertisement, I recognize that the company is still advertising itself. }\end{array}$ & .51 \\
\hline $\begin{array}{l}10 \text { I think about how advertisements can be designed to sway me with facts and } \\
\text { logic. }\end{array}$ & .52 \\
\hline $\begin{array}{l}11 \text { When watching or reading the news, I think about different purposes the } \\
\text { story might have. }\end{array}$ & .59 \\
\hline 12 I question a news story when credible sources for the ideas are not included. & .59 \\
\hline $\begin{array}{l}13 \text { When viewing an advertisement, I think about the effect the design has on } \\
\text { me. }\end{array}$ & .55 \\
\hline $\begin{array}{l}14 \text { When watching television, movies, or videos, I think about the lifestyles that } \\
\text { are being promoted. }\end{array}$ & .56 \\
\hline $\begin{array}{l}15 \text { I recognize that the political affiliations of news providers may influence } \\
\text { how news stories are reported. }\end{array}$ & .49 \\
\hline $\begin{array}{l}16 \text { When watching a television show, movie, or video, I think about whether or } \\
\text { not it would appeal to diverse populations. }\end{array}$ & .65 \\
\hline $\begin{array}{l}17 \text { I think about how the design of advertisements can draw my attention to } \\
\text { specific images. }\end{array}$ & .73 \\
\hline $\begin{array}{l}18 \text { I think about how news stories can be designed to elicit an emotional } \\
\text { response. }\end{array}$ & .74 \\
\hline $\begin{array}{l}19 \text { When viewing an advertisement, I think about whether or not it would } \\
\text { appeal to diverse populations. }\end{array}$ & .68 \\
\hline 20 I think about the strategies news reporters use in news stories. & .66 \\
\hline $\begin{array}{l}21 \text { I think about how advertisements can be designed to elicit an emotional } \\
\text { response. }\end{array}$ & .77 \\
\hline $\begin{array}{l}22 \text { When watching or reading the news, I think about whether or not any } \\
\text { images that are included accurately illustrate the content of the story. }\end{array}$ & .58 \\
\hline
\end{tabular}


23 When watching or reading the news, I think about how images can be altered to fit the content of the news story.

24 When viewing an advertisement, I distinguish between facts and opinions about the product.

25 I think about the strategies advertisers use to promote their products.

26 I think about why some advertisements may appeal to different audiences.

Next, item discrimination values were examined to determine how well each item can successfully differentiate between responses of students with a lower perceived level of media literacy and a higher perceived level of media literacy. Baker (2001) provides useful labels for discrimination parameter values: very low (.01-.34), low (.35-.64), moderate (.65-1.34), high (1.35-1.69), and very high (greater than 1.70). All items on the CEAM scale exhibit moderate discrimination parameter values or higher. Specifically, 15 items exhibit moderate discrimination parameter values (Items 01, 03, 05, 06, 07, 08, 09, 10, 11, 12, 13, 14, 15, 22, and 27); six items exhibit high discrimination parameter values (Items 02, 04, 16, 19, 20, and 26); and six items exhibit very high discrimination parameter values (Items $17,18,21,23,24$, and 25). See Table 3 for discrimination parameter values for each item.

Table 3.

Discrimination Parameter Values

\begin{tabular}{|c|c|c|c|}
\hline \multirow[b]{2}{*}{ Media Literacy Items } & \multicolumn{3}{|c|}{ Discrimination Parameter Values } \\
\hline & Moderate & High & $\begin{array}{l}\text { Very } \\
\text { High }\end{array}$ \\
\hline $\begin{array}{l}01 \text { When I watch a commercial, I pay attention to how the music } \\
\text { makes me feel. }\end{array}$ & .78 & & \\
\hline $\begin{array}{l}02 \text { I think about how television shows, movies, or videos can be } \\
\text { designed to elicit an emotional response. }\end{array}$ & & 1.37 & \\
\hline $\begin{array}{l}03 \text { I consider what viewpoints might be missing when I watch or } \\
\text { read the news. }\end{array}$ & 1.26 & & \\
\hline $\begin{array}{l}04 \text { I think about why some television shows, movies, or videos } \\
\text { may appeal to different audiences. }\end{array}$ & & 1.58 & \\
\hline $\begin{array}{l}05 \text { When watching television, movies, or videos, I think about the } \\
\text { effect the editing techniques have on me. }\end{array}$ & .88 & & \\
\hline $\begin{array}{l}06 \text { When watching or reading a news story, I think about whether } \\
\text { or not it would appeal to diverse populations. }\end{array}$ & 1.17 & & \\
\hline $\begin{array}{l}07 \text { I think about how news stories can be designed to sway me } \\
\text { with facts and logic. }\end{array}$ & 1.29 & & \\
\hline $\begin{array}{l}08 \text { I distinguish between expert sources and non-expert sources in } \\
\text { news stories. }\end{array}$ & 1.10 & & \\
\hline $\begin{array}{l}09 \text { If I see that a for-profit company is promoting a social cause in } \\
\text { an advertisement, I recognize that the company is still advertising } \\
\text { itself. }\end{array}$ & 1.02 & & \\
\hline $\begin{array}{l}10 \text { I think about how advertisements can be designed to sway me } \\
\text { with facts and logic. }\end{array}$ & 1.03 & & \\
\hline
\end{tabular}


11 When watching or reading the news, I think about different purposes the story might have.

12 I question a news story when credible sources for the ideas are not included.

13 When viewing an advertisement, I think about the effect the design has on me.

14 When watching television, movies, or videos, I think about the lifestyles that are being promoted.

15 I recognize that the political affiliations of news providers may influence how news stories are reported.

16 When watching a television show, movie, or video, I think

about whether or not it would appeal to diverse populations.

17 I think about how the design of advertisements can draw my attention to specific images.

18 I think about how news stories can be designed to elicit an emotional response.

19 When viewing an advertisement, I think about whether or not it would appeal to diverse populations.

20 I think about the strategies news reporters use in news stories.

21 I think about how advertisements can be designed to elicit an emotional response.

22 When watching or reading the news, I think about whether or not any images that are included accurately illustrate the content of the story.

23 When watching or reading the news, I think about how images can be altered to fit the content of the news story.

24 When viewing an advertisement, I distinguish between facts and opinions about the product.

25 I think about the strategies advertisers use to promote their products.

26 I think about why some advertisements may appeal to different audiences.

27 I recognize that different news stories are written to appeal to people who have different values.

Expected a posteriori (EAP) values were also examined to determine if respondents will perform as expected - those with a lower perceived media literacy level scoring lower and those with a higher perceived media literacy level scoring higher. Table 4 represents a snapshot of the EAP results.

\section{Table 4.}

Perceived Media Literacy Proficiency

\begin{tabular}{ll}
\hline Average Score & Expected A Posteriori \\
\hline 1 & -1.59 \\
2 & -0.25 \\
3 & 1.07 \\
4 & 3.69 \\
\hline
\end{tabular}


As expected, a student with a lower perceived media literacy level will score lower, and a student with a higher perceived media literacy level will score higher on the assessment.

Finally, item information function (IIF) and item characteristic curves (ICC) were also examined for each item in the scale. These results support the discrimination parameter values and EAP values.

One major benefit of IRT over CFA is that researchers have the opportunity to examine more item-level statistics, whereas the strength of CFA is in examining the factor-level structure. One of several item-level statistics unique to IRT is the discrimination parameter values. Item discrimination parameter values signify how well each individual item can differentiate between respondents of different abilities. In this case, the item discrimination parameter values signify how well each item differentiates between students with lower perceived media literacy levels and higher perceived media literacy levels.

As can be seen in Table 3, one trend in the discrimination parameter values is that items about advertising tend to have the highest capacity for differentiating between students of higher and lower perceived media literacy levels. However, items regarding credibility of news stories tend toward only moderately differentiating between students of higher and lower perceived media literacy levels. A second trend in the discrimination parameter values is that items that consider why media messages appeal to different audiences tend to have a high capacity for differentiating between students of higher and lower perceived media literacy levels.

Item information function (IIF) graphs and item characteristic curves (ICC) are also unique to IRT and can help to explain some of these trends. IIF graphs represent how well the item differentiates between responses of students with a lower perceived level of media literacy and students with a higher perceived level of media literacy. A flatter line in the graph means this item differentiates less, while a line with peaks means the item differentiates more. ICCs graphically represent the probability that a student with a lower or higher perceived level of media literacy will choose one of the five responses on the item, each represented by a different numbered and colored line. 
An examination of IIF graphs provides additional evidence for the first trend that while items about advertising tend to have the highest capacity for differentiating between students of different perceived media literacy levels, items about credibility in new stories tend toward only moderately differentiating between students of different perceived media literacy levels.

Item 24

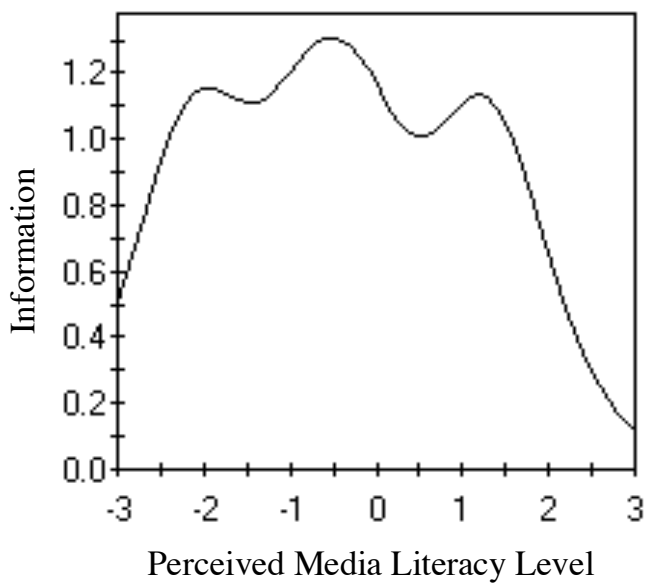

Item 8

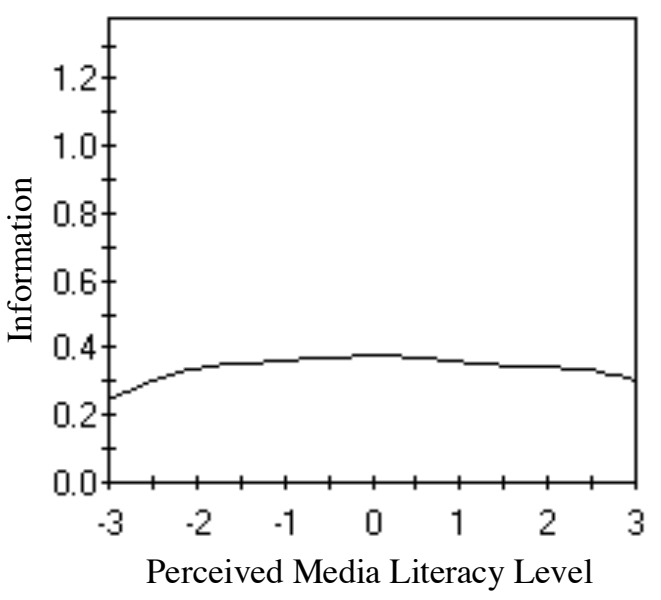

Figure 2.

Item information function for Item 24 ("When viewing an advertisement, I distinguish between facts and opinions about the product.") and Item 8 ("I distinguish between expert sources and non-expert sources in news stories."). This figure illustrates the capacity of items about advertisement and news to differentiate between students with different perceived media literacy levels.

In the first IIF graph in Figure 2, the IIF line is more peaked, meaning that Item 24 about credibility in advertisements does differentiate well between students with different perceived media literacy levels, especially for students with a low perceived media literacy level (around the -2.5 mark), a moderately low perceived media literacy level (around the -0.5 mark), and a good perceived media literacy level (around the 1.5 mark). On the other hand, in the second IIF graph in Figure 2, the IIF line is flatter, meaning Item 8 about credibility in news media does not differentiate as well between respondents who have lower and higher perceived levels of media literacy. 
Examination of ICCs also support the finding that items about advertising tend to have the highest capacity for differentiating between students of different perceived media literacy levels, while items about credibility in news stories tend toward only moderately differentiating between students of different perceived media literacy levels. ICCs illustrate the probability that a student with a lower or higher perceived level of media literacy will choose one of five responses on the item, each represented by a different colored and numbered line. See Figure 3.

Item 15

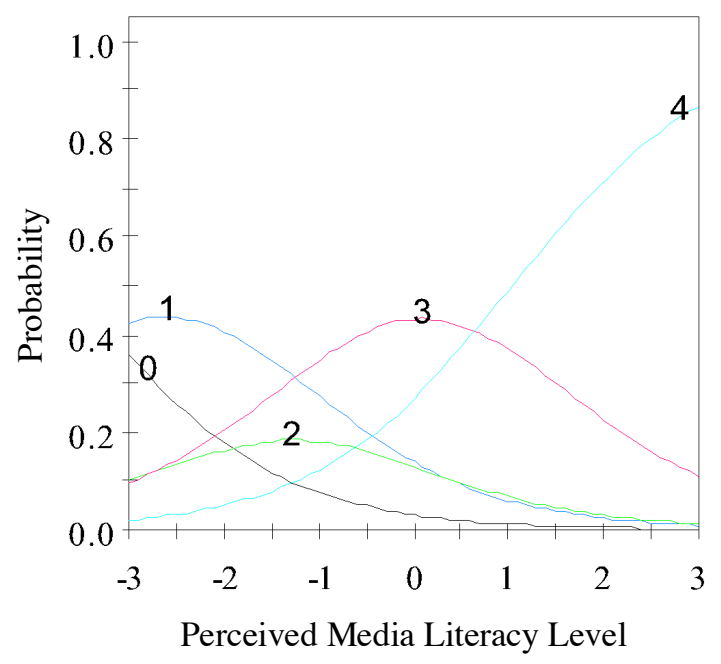

Item 25

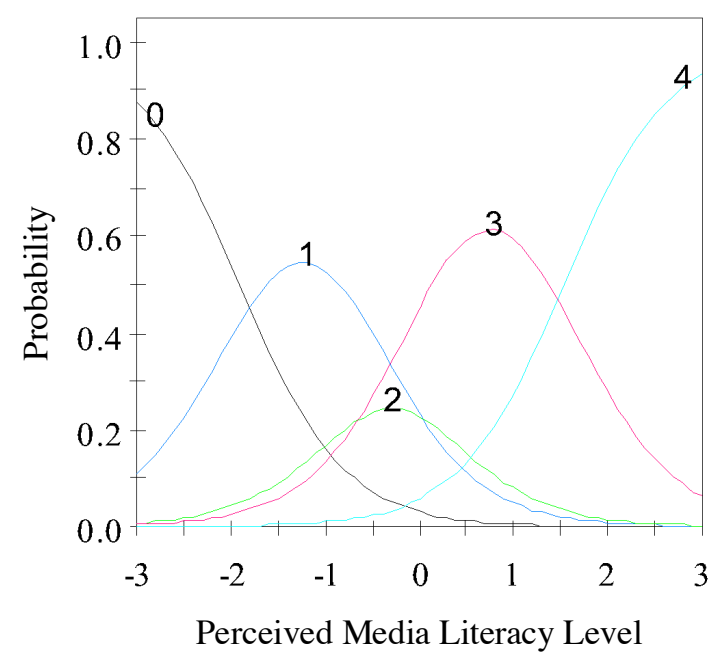

Figure 3.

Item characteristic curves for Item 15 ("I recognize that the political affiliations of news providers may influence how news stories are reported.") and Item 25 ("I think about the strategies advertisers use to promote their products."). This figure illustrates probability of students with different perceived media literacy levels to respond in a particular way to items about news and advertisement.

In Figure 3 for Item 15, which is focused on news, a student with a very low perceived level of media literacy (at the -3 point) is about $40 \%$ likely to choose the "disagree" response (trace line 1). This student is actually more likely to choose the "disagree" response (trace line 1) than the "strongly disagree" response (trace line 0 ), suggesting at least some confidence in news literacy. There is also about a $10 \%$ chance that a student with a very low perceived level of media literacy will choose the "undecided" response (trace line 2), and a 10\% chance that the same student will choose the "agree" response (trace line 3). By contrast, in Figure 3 for Item 25, which is focused on advertising, there is about a $90 \%$ chance that a student with a very low perceived level of media literacy will choose the "strongly disagree" response (trace line 0), while there is also about a $90 \%$ chance that a student with a very high perceived level of media literacy will choose the "strongly agree" response (trace line 4). Again, this supports the earlier results that items about advertising tend to yield more information than items about news with regard to how students with different perceived levels of media literacy might respond. 
Additionally, examination of ICCs support the second trend that items that consider why media messages appeal to different audiences tend to have a high capacity for differentiating between students of higher and lower perceived media literacy levels. Each item in Figure 4 deals with audience, and, in all cases, there is about an $80 \%$ chance that students with very low perceived media literacy levels are likely to answer "strongly disagree." On the other hand, for these items students with very high perceived media literacy levels are $60 \%-90 \%$ likely to answer "strongly agree." In all, examination of the ICCs in Figure 4 would suggest that students with lower perceived media literacy levels are not likely to respond that they think about how media messages reach different audiences, while students with higher perceived media literacy levels are likely to respond that they think about how media messages reach different audiences. See Figure 4 below.
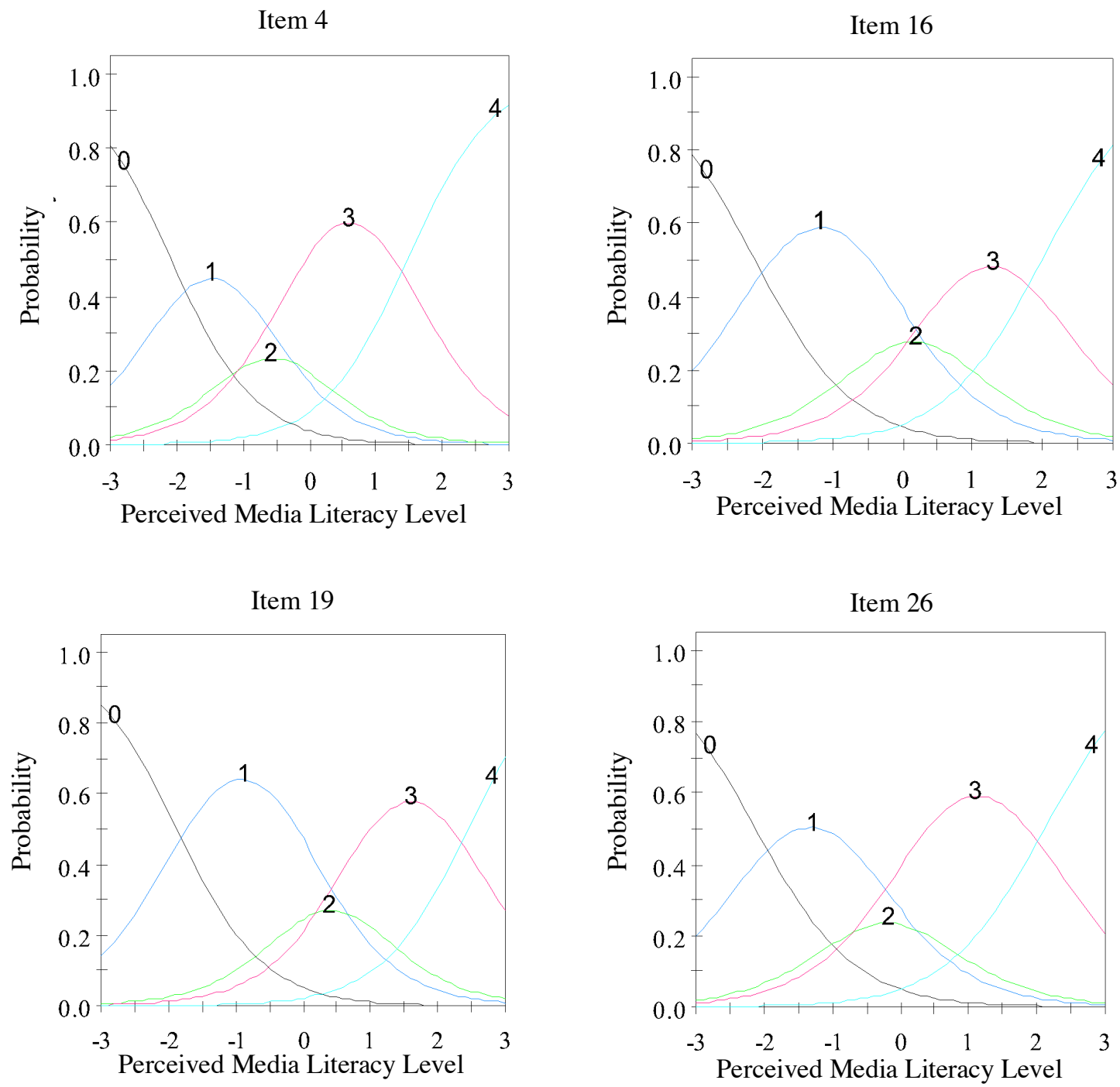

Figure 4. 
Item characteristic curves for Item 4, Item 16, Item 19, and Item 26. This figure illustrates probability of students with different perceived media literacy levels to respond in a particular way to items about audience.

These data support the finding that being able to recognize that media messages are targeted to different audiences is a competency that can help to differentiate media literacy levels.

\section{DISCUSSION AND IMPLICATIONS}

As both the CFA and IRT analyses confirm, the underlying structure of the instrument suggests that there are measureable strategies that students can practice for critically analyzing and evaluating visual media messages. These skills cut across type of media message (news, advertisement, and entertainment), which suggests that students can use the same set of skills to critically analyze and evaluate different types of media messages. Finally, the findings from the IRT analysis do support the use of CEAM as a generalizable, sample-free instrument. This means that CEAM can be used with consistency for any similar sample of college students. It is our hope that CEAM will be utilized by other researchers to further develop an understanding of the needs of college students for media literacy education.

Of particular interest among the findings from the IRT analysis is the trend that items about advertising tend to have the highest capacity for differentiating between students of higher and lower perceived levels of media literacy. This supports findings from a survey conducted by Schmidt (2013) that instructors at all levels (kindergarten through college) reported teaching less about advertisements and entertainment media (especially television and music).

In addition, the finding that items about advertising are more able to differentiate between students of different perceived media literacy levels than items about news makes sense after a review of the curriculum standards in K-12. Students are educated from an early age to be more conscious about the credibility of source information, such as news. The Common Core standards for history even include specific standards on distinguishing between fact and opinion, evaluating evidence, comparing points of view, and challenging claims in primary sources, secondary sources, and beyond (CCSS, 2016). Similarly, by the time students are juniors and seniors in high school, they should be able to write research papers in which they "gather relevant information from multiple authoritative print and digital sources, using advanced searches effectively" and "assess the strengths and limitations of each source in terms of the specific task, purpose, and audience" (CCSS, 2016).

This same kind of care is not stressed in K-12 or college education for advertisements, which is unfortunate during a time when native advertising is dominating our screens. Advertisements are now embedded in every form of media ranging from videos to social media to games. For this reason, it would be beneficial to further research media literacy of advertisements both in high school 
and in college. Toward this purpose, the CEAM scale may also have applications in high school classrooms.

The second trend - that items considering audience tend to have a high capacity for differentiating between students of higher and lower perceived media literacy levels - can also be traced back to theory. Rhetoricians and compositionists have been aware of the importance of audience since at least the point at which Aristotle theorized different modes of appeal to reach audiences. As such, audience is consistently included in English classrooms in K-12 through college. However, it is important to note that though students should come to college with this skill, items about targeted audience can still serve to identify students with lower perceived media literacy levels. This would suggest that college media literacy education can reinforce the skill of recognizing and targeting situational audiences.

The results of this study have implications for professional development of college instructors who teach media literacy. Because instructors self-report not focusing on the analysis and evaluation of advertisements, it might be useful to introduce professional development in this area.

In fact, professional development in media literacy education is an area that researchers agree needs our attention (Schmidt, 2013; Schwarz, 2014). As De Abreu and Mihailidis (2014) argue:

Media literacy is the field that will help us learn how to be critical, savvy, expressive, participatory, and engaged with media to help build a more vibrant, inclusive, and tolerant digital media culture. While media literacy takes many different shapes and forms, it is up to parents, teachers, scholars, and leaders to implement this movement that can help shape the future of teaching and learning about media's ever increasing role in the world. (p. xxviii)

As De Abreu and Mihailidis (2014) point out, the task of providing media literacy education at the college level falls on the shoulders of instructors. For this reason, professional development in media literacy is imperative. This is especially true for new instructors. Schmidt (2013) found that more experienced instructors are more likely to include media literacy education than less experienced instructors, despite age or status as a "digital native" (Prensky, 2001) or "digital immigrant" (Prensky, 2001).

Related to this, Nasah, DaCosta, and Kinsell (2010) found that digital propensity relies not just on age as the digital native myth would suggest, but on a combination of age, gender, and socioeconomic status; they suggest that educators and policymakers consider more closely demographic implications when making decisions about media literacy education. So, if issues like socioeconomic status are at play, then it is important to consider previous access to and engagement with media that students may have had.

However, researchers (Gee, 2014; Livingstone \& Wang, 2014; Pernisco, 2014) agree that simply improving equal access to media will not close gaps between students with different levels of preparation and privilege. For a more 
equitable education, media literacy education is crucial at the college level, and one area needing immediate attention is advertising literacy.

\section{REFERENCES}

Arke, E., \& Primack, B. (2009). Quantifying media literacy: Development, reliability, and validity of a new measure. Educational Media International, 46(1), 53-65.

Ashley, S., Lyden, G., \& Fasbinder, D. (2012). Exploring message making: A qualitative media literacy study of college freshmen. Journal of Media Literacy Education, 4(3), 229-243. Retrieved from http://jmle.org/index.php/JMLE/article/view/244/214

Baker, F. B. (2001). The basics of item response theory. Retrieved from http://files.eric.ed.gov/fulltext/ED458219.pdf

Bordac, S. (2009). Identifying undergraduate media literacy skills: An exploratory study of faculty perceptions. Proceedings of the American Society for Information Science and Technology, 46(1), 1-16.

Brown, T. (2006). Confirmatory factor analysis for applied research. New York, NY: Guilford Publications.

Brumberger, E. (2011). Visual literacy and the digital native: An examination of the millennial learner. Journal of Visual Literacy, 30(1), 19-46.

Chang, C. S., Liu, E. Z. F., Lee, C. Y., Chen, N. S., Hu, D. C., \& Lin, C. H. (2011). Developing and validating a Media Literacy Self-Evaluation Scale (MLSS) for elementary school students. The Turkish Online Journal of Educational Technology, 10(2), 63-71.

Christ, W. G. (2004). Assessment, media literacy standards, and higher education. American Behavioral Scientist, 48(1), 92-96.

Cohen, R.J., Swerdlik, M.E., \& Smith, D.K. (2012). Psychological testing and assessment: An introduction to tests and measurement (8th ed.). Mountain View, CA: Mayfield Publishing Company.

Common Core State Standards (CCSS). (2016). English language arts standards. Retrieved from http://www.corestandards.org/ELA-Literacy/

Comrey, A. L., \& Lee, H. B. (1992). A first course in factor analysis. Hillsdale, NJ: Lawrence Erlbaum Associates.

De Abreu, B. S., \& Mihailidis, P. (2014). Introduction. In B. S. De Abreu \& P. Mihailidis (Eds.), Media literacy education in action: Theoretical and pedagogical perspectives (pp. xxiii-xxx). New York, NY: Routledge.

De Ayala, R. J. (2009). The theory and practice of item response theory. New York, NY: Guilford.

Duran, R. L., Yousman, B., Walsh, K. M., \& Longshore, M. A. (2008). Holistic media education: An assessment of the effectiveness of a college course in media literacy. Communication Quarterly, 56(1), 49-68. doi:10.1080/01463370701839198

Embretson, S. E., \& Reise, S. P. (2000). Item response theory for psychologists. Mahwah, NJ: Erlbaum. 
Engeln-Maddox, R., \& Miller, S. A. (2008). Talking back to the media ideal: The development and validation of the Critical Processing of Beauty Images Scale. Psychology of Women Quarterly, 32, 159-171. doi:10.1111/j.14716402.2008.00420.x

Eristi, B., \& Erdem, C. (2017). Development of a media literacy skills scale. Contemporary Educational Technology, 8(3), 249-267.

Gable, R. K., \& Wolf, M. B. (1993). Instrument development in the affective domain. Boston, MA: Kluwer Academic Publishers.

Gee, J. P. (2014). Literacy and education. New York, NY: Routledge.

Hambleton, R. K., Swaminathan, H., \& Rogers, H. J. (1991). Fundamentals of item response theory. Newbury Park, CA: Sage Publications.

Hobbs, R., \& Frost, R. (2003). Measuring the acquisition of media-literacy skills. Reading Research Quarterly, 38(3), 330-355. doi:10.1598/RRQ.38.3.2

Jolls, T., \& Walkosz, B. J. (2014). Voices of media literacy. In B. S. De Abreu \& P. Mihailidis (Eds.), Media literacy education in action: Theoretical and pedagogical perspectives (pp. 11-19). New York, NY: Routledge.

Kellner, D., \& J. Share. (2005). Toward Critical Media Literacy: Core concepts, debates, organizations, and policy. Discourse: Studies in the Cultural Politics of Education, 26(3), 369-386.

Literat, I. (2014). Measuring new media literacies: Towards the development of a comprehensive assessment tool. Journal of Media Literacy Education, $6(1), 15-27$.

Livingstone, S., \& Wang, Y. (2014). On the difficulties of promoting media literacy. In B. S. De Abreu \& P Mihailidis (Eds.), Media literacy education in action: Theoretical and pedagogical perspectives (pp. 162172). New York, NY: Routledge.

Martens, H. (2010). Evaluating media literacy education: Concepts, theories and future directions. Journal of Media Literacy Education, 2(1), 1-22.

Messick, S. (1987). Validity. Journal of Educational Research and Statistics Research Report Series, 2, (i-208). doi:10.1002/j.23308516.1987.tb00244.x

Mihailidis, P. (2011). (Re)mix, (re)purpose, (re)learn: Using participatory tools for media literacy learning outcomes in the classroom. Action in Teacher Education, 33(2), 172-183. doi:10.1080/01626620.2011.569421

Nasah, A., DaCosta, B., \& Kinsell, C. (2010). The digital literacy debate: An investigation of digital propensity and information and communication technology. Education Technology Research Development, 58(5), 531555. doi:10.1007/s11423-010-9151-8

Nunnally, J. C. (1978). Psychometric theory (2nd ed.). New York: McGraw Hill.

Pernisco, N. (2014). Shrinking the Divide: Solving social inequalities through media literacy education. In B. S. De Abreu \& P. Mihailidis (Eds.), Media literacy education in action: Theoretical and pedagogical perspectives (pp. 147-152). New York, NY: Routledge.

Pew Research Center. (2011). College students and technology. The Pew Charitable Trusts. Retrieved from http://www.pewinternet.org/2011/07/19/college-students-and-technology/ 
Pew Research Center. (2014). 13 things to know about teens and technology. The Pew Charitable Trusts. Retrieved from http://www.pewinternet.org/2014/07/23/13-things-to-know-about-teensand-technology/

Pew Research Center. (2015). While less-educated adults are catching up, their internet adoption rates are still below those of college graduates. The Pew Charitable Trusts. Retrieved from http://www.pewinternet.org/chart/whileless-educated-adults-are-catching-up-their-internet-adoption-rates-arestill-below-those-of-college-graduates/

Pew Research Center. (2017). Internet use by education. The Pew Charitable Trusts. Retrieved from http://www.pewinternet.org/chart/internet-use-byeducation/

Potter, J. W., \& Byrne, S. (2009). Media literacy. In R. L. Nabi \& M. B. Oliver (Eds.), The Sage handbook of media processes and effects (pp. 345-357). Thousand Oaks, CA: Sage.

Prensky, M. (2001). Digital natives, digital immigrants. On the Horizon, 9(5), 16. Retrieved from www.marcprensky.com/writing

Price, L. (2016). Psychometric methods: Theory into practice. New York, NY: Guilford.

Primack, B. A., Gold, M. A., Switzer, G. E., Hobbs, R., Land, S. R., \& Fine, M. J. (2006). Development and validation of a Smoking Media Literacy Scale for adolescents. Archives of Pediatrics and Adolescent Medicine, 160(4), 569-374. doi:10/1001/archpedi.160.4.369

Quin, R., \& McMahon, B. (1993). Evaluating standards in media education. Canadian Journal of Educational Communication, 22(1), 15-25.

Schmidt, H. C. (2012). Media, millennials, and the academy: Understanding the state of media literacy within higher education. Journal on Excellence in College Teaching, 23(4), 54-75.

Schmidt, H. C. (2013). Media literacy education from kindergarten to college: A comparison of how media literacy is addressed across the educational system. Journal of Media Literacy Education, 5(1), 296-309.

Schumacker, R. E., \& Lomax, R. G. (2010). A beginner's guide to structural equation modeling (3rd ed.). New York, NY: Routledge.

Schwarz, G. (2014). Rhetoric in a new key: Media literacy education for the twenty-first-century university. In B. S. De Abreu \& P Mihailidis (Eds.), Media literacy education in action: Theoretical and pedagogical perspectives (pp. 213-218). New York, NY: Routledge.

Silverblatt, A. (2014). Curriculum developments in higher education, media literacy. The Praeger handbook of media literacy: Volume 1. Santa Barbara, CA: Praeger.

Tabachnick, B. G., \& Fidell, L. S. (2013). Using multivariate statistics. Boston, MA: Allyn and Bacon.

Vraga, E., Tully, M., Kotcher, J. E., Smithson, A., \& Broeckelman-Post, M. (2016). A multi-dimensional approach to measuring news media literacy. Journal of Media Literacy Education, 7(3), 41-53. 